\title{
TO STUDY ZINC DEFICIENCY AS A RISK FACTOR FOR FEBRILE CONVULSIONS
}

\author{
Pinnaka Subbarao', Puttagunta Sree Apoorva2, Kathiravan $K^{3}$, P. Ramachandran ${ }^{4}$ \\ ${ }_{1}^{1}$ Assistant Professor, Department of Paediatrics, Sri Ramachandra Institute of Higher Education and Research Institute, Chennai, \\ Tamilnadu, India. \\ ${ }^{2}$ Resident, Department of Paediatrics, Sri Ramachandra Institute of Higher Education and Research Institute, Chennai, Tamilnadu, \\ India. \\ ${ }^{3}$ Resident, Department of Paediatrics, Sri Ramachandra Institute of Higher Education and Research Institute, Chennai, Tamilnadu, \\ India. \\ 4Professor, Department of Paediatrics, Sri Ramachandra Institute of Higher Education and Research Institute, Chennai, Tamilnadu, \\ India.
}

\section{ABSTRACT}

\section{BACKGROUND}

Febrile seizure is the most common type of seizure that affects children under 5 years of age. Micronutrient deficiencies like zinc deficiency, have been linked with febrile seizures in children. We wanted to determine the correlation between zinc deficiency and febrile seizures in children aged between 6 months and 6 years of age.

\section{METHODS}

This case control study was held in a tertiary care centre in 2013. 75 children aged 6 months to 60 months with first/recurrent episode of febrile seizures constituted the cases. Age and sex matched controls with non-seizure febrile illness were taken as controls. Zinc levels in both groups were compared.

\section{RESULTS}

Mean serum zinc levels among the febrile seizure group [54.53 mcg/dl] was much lesser than that in control group [89.88 mcg/dl] and the difference was statistically significant with $\mathrm{p}$ value of $<0.05$.

\section{CONCLUSION}

Hypozincaemia was observed in children with febrile seizures. However large prospective trials are needed to confirm the association.

HOW TO CITE THIS ARTICLE: Subbarao P, Apoorva PS, Kathiravan K, et al. To study zinc deficiency as a risk factor for febrile convulsions. J. Evolution Med. Dent. Sci. 2019;8(15):1208-1211, DOI: 10.14260/jemds/2019/267

\section{BACKGROUND}

The International League Against Epilepsy [ILAE] defines a febrile seizure $[\mathrm{FS}]$ as a seizure occurring in childhood after one month of age, associated with a febrile illness which is not due to infection of the central nervous system. FS are the most common; 2 to $5 \%$ of children younger than 5 years of age with peak incidence in the second year of life. ${ }^{1}$

FS are common between 6 months to 5 years of age with febrile episodes, that are not associated with any central nervous system infection or any metabolic abnormalities and without history of previous afebrile seizures. ${ }^{2}$

Aetiology of febrile seizures includes bacterial and viral infections, 3 vulnerability of the immature brain to fever, 4 association with interleukins, circulatory toxins, 5 trace element deficiency, iron deficiency ${ }^{6}$ and role of genetics as triggering factor.

Some elements because of their coenzyme activity and their impact on receptors and ion channels, understood to have an important role in febrile seizures.

'Financial or Other Competing Interest': None.

Submission 02-03-2019, Peer Review 01-04-2019,

Acceptance 05-04-2019, Published 15-04-2019.

Corresponding Author:

Puttagunta Sree Apoorva

D/o. P. Venkata Ramana,

5-80-2, Sreenivasam, $3^{\text {rd }}$ Floor,

Ashoknagar $1^{\text {st }}$ Lane, Guntur, Tamilnadu, India.

E-mail: a18appu92@icloud.com

DOI: $10.14260 /$ jemds $/ 2019 / 267$
Studies have shown that iron, zinc, magnesium, selenium and copper are highly effective in febrile seizures. ${ }^{7}$

Zinc is one of the essential minerals that plays a major role in prevention and treatment of neurological disease. ${ }^{8}$ Hippocampus contains highest zinc concentration. ${ }^{8}$

Zinc is an important factor for growth, development and normal function of the brain and a significant cofactor for DNA and RNA polymerase enzymes. ${ }^{9}$

Zinc regulates the glutamic acid activity and the rate limiting enzyme in the synthesis of an inhibitory enzyme the gamma -amino butyric acid [GABA].10 Any abnormalities of GABAergic function, including synthesis, synaptic release, receptor composition, trafficking or binding and metabolism can lead to hyper excitable epileptic state.11,12 Children with simple febrile seizures has risk for recurrence and $2-7 \%$ of children may develop epilepsy by adolescence.13,14 Zinc also facilitates the inhibitory effect of calcium on N-Methyl-daspartate receptors [NMDA], these effects prevent the stimulation of neuronal discharge. ${ }^{15}$

Studies have shown that Zinc has significant role in the pathogenesis of febrile seizures.

The present study intends to estimate the serum zinc level in children with febrile seizures and those only with fever.

This study will help in formulation of guidelines for zinc supplementation as part of management of febrile seizures and will help in prevention of recurrent febrile seizures. 


\section{METHODS}

The proposed study was a hospital based prospective case control study with 75 children as cases [Febrile seizures ] and 75 children as control [febrile episode]. This study was conducted in Sri Ramachandra Medical College \& Research Institute, Chennai [India] in 2013. Ethics committee of our institute approved the study design before the initiation of enrolment. Informed written consent was taken from parents /legal guardians of both cases and controls. Both groups were matched for age, sex, weight and height. Children between 6 months to 60 months of age with a diagnosis of simple febrile seizures both first and recurrent episodes were recruited as cases. Children admitted in the hospital for febrile illness without seizures were taken as controls. Controls were matched to cases on three age groups [ $<1$ year, 1-3 years, and $>3$ years].

\section{Exclusion Criteria}

- $\quad$ Children with complex febrile seizures.

- Children with diarrhoea, receiving zinc preparations and children with other neurological abnormalities like cerebral palsy, neurodegenerative disorders, neuroanatomical malformations, seizure disorder.

\section{Methodology}

A pre designed proforma was used to collect the relevant information. Details of age, sex, developmental milestones, family history of febrile seizure, epilepsy, underlying illness and clinical examinations were recorded for cases and control groups. Details of seizure type, duration, frequency were recorded and classified as simple and complex febrile seizures and investigated. Blood samples collected from all cases and control groups, estimated for zinc deficiency. The sample size was taken for conveniences.

Serum zinc level of $<70$ micro gm/dl was considered as deficiency. All children detected to have deficiency were started on zinc supplements and reviewed on OP basis.

\section{Statistical Analysis}

All observations were tabulated and analysed using Fisher's exact test, independent student ' $t$ ' test for checking the significance with $\mathrm{p}<0.05$ considered as statistically significant. SPSS software 17.0 version was used for analysing the data.

\section{RESULTS}

\begin{tabular}{|c|c|c|}
\hline Characteristics & $\begin{array}{c}\text { Febrile Seizures } \\
\text { [Cases] }\end{array}$ & Controls \\
\hline Mean Age in Months & 20.4 & 21.6 \\
\hline $\begin{array}{c}\text { Protein Energy Malnutrition } \\
\text { [Grade I \&II] }\end{array}$ & $20 \%$ & $22.9 \%$ \\
\hline \multicolumn{3}{|l|}{ Underlying Cause of Illness } \\
\hline Viral fever & $68 \%$ & $52 \%$ \\
\hline URI & $2.6 \%$ & $5.3 \%$ \\
\hline LRI & $8 \%$ & $32 \%$ \\
\hline UTI & $2.6 \%$ & $5.3 \%$ \\
\hline Gluteal Abscess & $2.6 \%$ & $0.0 \%$ \\
\hline $\begin{array}{c}\text { Others [Including Acute } \\
\text { Gastroenteritis] }\end{array}$ & $0.0 \%$ & $5.3 \%$ \\
\hline \multicolumn{3}{|c|}{$\begin{array}{c}\text { Table 1. Demographic Characteristics and Underlying } \\
\text { Cause of Illnesses Among Cases of Febrile Seizures and } \\
\text { Controls }\end{array}$} \\
\hline
\end{tabular}

\begin{tabular}{|c|c|c|c|}
\hline & Cases [SD] & Controls [SD] & p Value \\
\hline $\begin{array}{c}\text { Mean Hb } \\
\text { Level (SD) }\end{array}$ & $10.8(4.5) \mathrm{mg} / \mathrm{dl}$ & $10.53(3.9) \mathrm{mg} / \mathrm{dl}$ & 0.05 \\
\hline \multicolumn{4}{|c|}{ Table 2. Mean Levels of Haemoglobin Between Cases and } \\
Controls \\
\hline
\end{tabular}

\begin{tabular}{|c|c|c|c|}
\hline Zinc Levels & Cases [SD] & Controls [SD] & p Value \\
\hline Mean (SD) & $\begin{array}{c}54.53(24.5) \\
\mathrm{mcg} / \mathrm{dl}\end{array}$ & $\begin{array}{c}89.88(31.3) \\
\mathrm{mcg} / \mathrm{dl}\end{array}$ & 0.05 \\
\hline \multicolumn{4}{|c|}{ Table 3. Mean Levels of Zinc Between Cases and Controls } \\
\hline
\end{tabular}

Mean serum zinc level p value was 0.05 and haemoglobin level $P$ value of 0.05 is significant in cases when compared to controls. Underlying cause of illness: With regards to underlying cause of illness, viral fever was most common (68\%), followed by respiratory tract infections (8\%), Urinary tract infections (2.6\%).

\section{DISCUSSION}

Febrile convulsion is one of the major causes of admission in paediatric ward that occurs in between 6 months and 60 months aged children. The reason behind this condition is still not known. Febrile convulsions affect $2-5 \%$ of children in this age group and account for approximately $30 \%$ of all seizure disorders in children.

Zinc plays a regulatory role in the immune system, and Zinc-deficient persons experience increased response to a variety of pathogens. It also functions as an antioxidant and can stabilize membranes. It is also proved that reduction in serum zinc concentrations can be due to fever and /or infections. 10

With this background, this study was conducted to identify the role of zinc in the causation of febrile seizures in children. It was decided to have a control group of children with fever of short duration as zinc is known to be reduced non-specifically in any fever. ${ }^{12}$

Febrile seizures were common in males [71\%] than in females but the sex difference was not statistically significant between study and control groups. This is similar to the study by Ganesh et al. 16

In our study the main cause of febrile seizure was viral fever among cases followed by respiratory tract infections, urinary tract infection and gluteal abscess with similar kind of findings noticed in Seema Pravin Soni et al. ${ }^{17}$ Study done by Margaretha and Gunduz ${ }^{18,19,20}$ have reported acute respiratory infection as the major cause.

Not many studies have been conducted regarding zinc deficiency as one of the causes for occurrence of febrile seizures. A study done by Ehsanipoor et $\mathrm{al}^{21}$, children between 6 months to 5 years of age were classified into three groups like children with febrile seizures, children with fever without convulsion and children with convulsions without fever. Mean serum zinc levels for these groups was $76 \pm$ 24.36, $90.12 \pm 14.36,94 \pm 17.39$, respectively. There was a significant difference between $\mathrm{Zn}$ serum levels in the three groups and children with FS, serum zinc levels were significantly lower than for the other two groups.

Similarly, study done by Ali Khajeh et al22 showed that the zinc level in children with febrile seizures was significantly lower than in children with non-febrile seizures. In our study among two groups i.e. children with febrile seizures and children with fever without convulsion. Mean serum zinc 
levels for these two groups were $51.49 \pm 63$ among cases and $73.85 \pm 97.29$ among controls.

Children with first episode of febrile seizures had a mean serum zinc level of 54.25 and children with multiple episodes had a level of 55.23 with not a significant difference.

In our study mean haemoglobin level of $10.8 \mathrm{mg} / \mathrm{dl}$ in the cases against $10.5 \mathrm{mg} / \mathrm{dl}$ in controls denoting that there was no difference in $\mathrm{Hb}$ levels among cases and controls. Yousefichaijan $\mathrm{P}$ et al ${ }^{23}$ on the relationship between iron deficiency anaemia and simple febrile convulsion in children observed that the prevalence of anaemia in the group with febrile convulsion was significantly less than that in the control group: $22.5 \%$ of the children in the group with febrile convulsion and $34 \%$ in the control group exhibited anaemia $(\mathrm{P}<0.001)$

The limitation in our study was that we only compared Haemoglobin between the groups but not the peripheral smear or ferritin levels.

A study carried out by LEE and $\mathrm{Kim}^{24}$ aimed at comparison of the Zinc level in patients with febrile seizures and those with seizures without fever [non febrile seizures] showed the Zinc level in children with febrile seizures was significantly lower than in children with non-febrile seizures. Similar result was noticed in our study with statistical significance $[\mathrm{p}<0.01]$.

Serum zinc level difference between sexes was not statistically significant in the study in both cases and controls similar to the study by Ganesh et al. ${ }^{16}$

Gunduz et $\mathrm{al}^{20}$ conducted a study to detect the levels of serum and csf Zinc who had febrile seizures. They noticed that there was a decrease in CSF and Serum zinc levels during infectious diseases, and that this decrease was more significant in patients with febrile convulsion.

As a limitation of our study CSF zinc levels were not measured.

CSF hypozincaemia activates N-Methy -D -Aspartate receptors or disinhibits GABAergic action, thus resulting in febrile convulsion. 25

Zinc acts as a neurotransmitter and improves the locomotive and communicating function, and also neurological system evolution. 26 Zinc deficiency decreases hippocampal zinc and leads to seizure discharge. ${ }^{27}$ However, the mechanism of this decreased serum zinc level in the febrile seizure group is not clearly understood. Some studies showed that factors like the time of day, the specific disease, or the presence of other trace elements. ${ }^{28}$ Therefore, a study design considering these effects is needed to further explain hypozincaemia in febrile seizure children.

To conclude, we detected that febrile seizures are commonly seen in children with low zinc levels compared to children with non-febrile seizures. There was no statistical significance with other factors like age, sex, nutrition status, number of episodes, haemoglobin status among the cases and controls.

\section{CONCLUSIONS}

- Serum zinc levels in children with simple febrile seizures were significantly low when compared with febrile children without seizures.

- $\quad$ There was a male predominance in children presenting with febrile seizures.
- Viral fever was the most common diagnosis seen in febrile seizures.

\section{Limitations}

- $\quad$ The study population was a small group of only 70.

- $\quad$ Relationship between CSF zinc level and febrile seizures was not analysed.

- Follow-up was not carried out.

\section{REFERENCES}

[1] Shinnar S. Febrile seizures and mesial temporal sclerosis. Epilepsy Curr 2003;3(4):115-8.

[2] Wanigasinghe J. Febrile seizures (Review). Sri Lanka Journal of Child Health 2009;38:93-7.

[3] Millichap JG, Millichap JJ. Role of viral infections in the etiology of febrile seizures. Pediatr Neurol 2006;35(3):165-72.

[4] Holtzman D, Obana K, Olson J. Hyperthermia - induced seizures in the rat pup: a model for febrile convulsions in children. Science 1981;213(4511):1034-6.

[5] Virta M, Hurme M, Helminen M. Increased plasma levels of pro-and anti-inflammatory cytokines in patients with febrile seizures. Epilepsia 2002;43(8):920-3.

[6] Kumari PL, Nair MK, Nair SM, et al. Iron deficiency as a risk factor for simple febrile seizures--a case control study. Indian Pediatr 2012;49(1):17-9.

[7] Srinivasa S, Manjunath MN. Serum zinc levels in children with febrile seizures. Journal of Evolution of Medical and Dental Sciences 2014;3(12):2983-8.

[8] Yang Y, Jing XP, Zhang SP, et al. High dose zinc supplementation induces hippocampal zinc deficiency and memory impairment with inhibition of BDNF signaling. PLoS One 2013;8(1):e55384.

[9] Salgueiro MJ, Zubillaga MB, Lysionek AE, et al. The role of zinc in the growth and development of children. Nutrition 2002;18(6):510-9.

[10] Garty BZ, Olomucki R, Lerman-Sagie $\mathrm{T}$, et al. Cerebrospinal fluid zinc concentrations in febrile convulsions. Arch Dis Child 1995;73(4):338-41.

[11] Mehta S. Role of zinc in febrile seizures in children. European Journal of Biomedical and Pharmaceutical Sciences 2017;4(4):531-3.

[12] Macdonald RL, Kang JQ. Molecular pathology of genetic epilepsies associated with GABAA receptor subunit mutations. Epilepsy Curr 2009;9(1):18-23.

[13] Habib Z, Akram S, Ibrahim S, et al. Febrile seizures: factors affecting risk of recurrence in Pakistani children presenting at the Aga Khan University Hospital. J Pak Med Assoc 2003;53(1):11-7.

[14] Elkis LC. Crises sintomaticas agudas. In: Manreza MLG, Grossmann RM, Valerio RMF, et al. eds. Epilepsia (infancia e adolescencia) Sao Paulo: Lemos Editorial 2003: p. 207-28.

[15] Takeda A. Movement of zinc and its functional significance in the brain. Brain Res Rev 2000;34(3):137-48.

[16] Ganesh R, Janakiraman L. Serum Zinc levels in children with simple febrile seizure. Clin Pediatr (Phila) 2008;47(2):164-6. 
[17] Soni SP, Une L. Role of serum zinc level in simple febrile seizures: a hospital based study from rural area of Maharashtra. MedPulse International Journal of Paediatrics 2017;3(2):36-8.

[18] Margaretha L, Masloman N. Correlation between serum Zinc level and simple febrile seizure in children. Pediatr Indones 2010;50(6):326-30.

[19] Mayhar A, Pahlavan AA, Varasteh -Nijad A. Serum Zinc level in children with febrile seizure. Acta Medica Iranica 2008;46(6):477-80.

[20] Gündüz Z, Yavuz I, Koparal M, et al. Serum and cerebrospinal fluid zinc levels in children with febrile convulsions. Acta Paediatr Jpn 1996;38(3):237-41.

[21] Ehsanipour F, Talebi-taher ME, Harandi NV, et al. Serum Zinc level in children with febrile convulsion and its comparison with that of control group. Iran J Pediatr 2009;19(1):65-8.

[22] Khajeh A, Miri-Aliabad G, Fayyazi A, et al. Serum zinc level in children with febrile convulsion. Zahedan Journal of Research in Medical Sciences 2016;18(1).
[23] Yousefchaijan P, Eghbali A, Rafeie M, et al. The relationship between iron deficiency anemia and simple febrile convulsion in children. Journal of Pediatric Neurosciences 2014;9(2):110-4.

[24] Lee JH, Kim JH. Comparison of serum zinc levels measured by inductively coupled plasma mass spectrometry in preschool children with febrile and afebrile seizures. Annals of Laboratory Medicine 2012;32(3):190-3.

[25] Izumi Y, Ishii K, Akiba K, et al. Hypozincemia during fever may trigger febrile convulsion. Med Hypothesis 1990;32(1):77-80.

[26] Mahyar A. The preventive role of zinc from communicable and non-communicable diseases in children. Non-Communicable Disease (NCD) Malaysia 2005;4:21-5.

[27] Tapiero H, Tew KD. Trace elements in human physiology and pathology: zinc and metallothioneins. Biomed Pharmacother 2003;57(9):399-411.

[28] Maret W, Sandstead HH. Zinc requirements and the risks and benefits of zinc supplementation. J Trace Elem Med Biol 2006;20(1):3-18. 